\section{Dutch, English and African shipbuilding craftsmanship in precolonial West Africa: An entangled history of construction, maintenance and repair}

\section{Filipa Ribeiro da Silva}

International Institute of Social History, Amsterdam, The Netherlands
The International Journal of Maritime History 2019, Vol. 3I(3) 508-520 (C) The Author(s) 2019 Article reuse guidelines: sagepub.com/journals-permissions DOI: I0.I I77/084387|4|9862I69 journals.sagepub.com/home/ijh

(SAGE

\begin{abstract}
In comparative perspective, this article examines the shipping, construction, maintenance and repair of Dutch and English ships, boats and canoes operating in West Africa during the precolonial period. In addition, I discuss the strategies adopted by Dutch, English, and other 'nations' of merchants present in the various coastal regions of the African continent, to cope with the challenges posed by port-to-port navigation and transportation in shallow river estuaries along the western coast of Africa. Among these strategies were the transport of pre-fabricated boats of small dimension to the coast on board of heavier ships and recruitment of personnel specialised in ship repair and shipbuilding, to the acquisition, either temporary or permanent, of African boats and recruitment of African boatmen. In this way, merchants' success on the coast was dependent on both European and African shipbuilding craftsmanship and navigational skills. Our analysis is based on information gathered from travelogues, journals of voyages and collections of correspondence exchanged between European merchants and their commercial agents based in Africa, and between officials of the private European commercial companies on the African coast.
\end{abstract}

Keywords

Dutch, English, precolonial, shipbuilding, ship repair, West Africa 


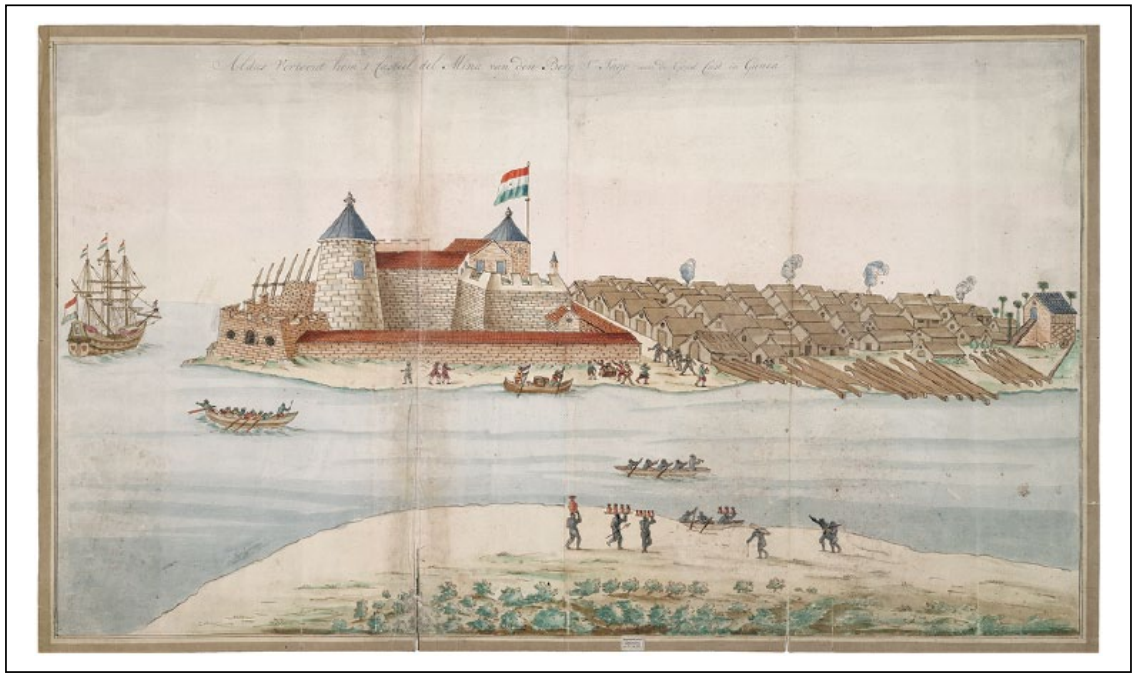

Figure I. View of Elmina, 1706.

Source: National Archive (The Netherlands), Aanwinsten Kaarten 4AANW, Inventory no. 1568.

The View of Elmina dating from 1706 (see Figure 1) depicts in detail the main Dutch castle on the Gold Coast and the vessels the Dutch used in their long-distance and coastal trades, and for patrolling and defending their commercial interests in the region. The emphasis the illustration gives to the various types of ships and canoes on shore provided viewers in those days with detailed information about Dutch naval power, while also providing modern researchers with useful data for studying Dutch shipbuilding overseas during that period.

In the past few decades, scholars have paid considerable attention to the shipbuilding activities in the Dutch Republic ('the Republic') that enabled the Dutch to pursue maritime expansion and to establish themselves as an overseas power. ${ }^{1}$ An extensive body of literature has also been published on Dutch shipping and trading activities overseas. So far, however, little is yet known about Dutch shipbuilding activities overseas, including in West Africa. And while several scholars have devoted attention to Dutch coastal trade in West and West Central Africa, as well as to the recruitment and employment of workers of European and African origin in these shipping and defensive activities, ${ }^{2}$ no in-depth studies have been conducted of the shipbuilding, ship repair and ship maintenance

1. See, among others, Richard W. Unger, 'The Rise of the Dutch Shipbuilding Industry: ca. 1400 - ca. 1600' (unpublished PhD dissertation, Yale University, 1971); J. R. Bruijn, ed., Maritieme Geschiedenis der Nederlanden, 4 vols (Bussum, 1976-1978); J. R. Bruijn, The Dutch Navy of the Seventeenth and Eighteenth Centuries (Columbia, SC, 1993); J. R. Bruijn and F. S. Gaastra, eds., Ships, Sailors and Spices. East India Companies and Their Shipping in the 16th, 17th and 18th Centuries (Amsterdam, 1993).

2. See, among others, Alan F. C. Ryder, 'Dutch Trade on the Nigerian Coast during the Seventeenth Century', Journal of the Historical Society of Nigeria, 3: 2 (1965) 195-210; Harvey M. Feinberg, Africans and Europeans in West Africa: Elminans and Dutchmen on 
activities carried out by the Dutch on the African coast. Neither has any examination been conducted of how these practices compared with those of other Europeans. Similarly, little has so far been published on how the Dutch and other Europeans met their needs for ship repairs and maintenance on the coast, and how they acquired and provisioned the light boats and canoes they used for coastal navigation purposes. ${ }^{3}$

This article partially bridges this gap in the literature by examining, in comparative perspective, the shipping, construction, maintenance and repair of Dutch and English ships, boats and canoes operating in West Africa during the precolonial period. Port-to-port navigation and transportation in shallow river estuaries along the west coast of Africa posed challenges to all European merchants and military as far as shipping capacity, design and shipbuilding were concerned. To cope with these challenges, the Dutch, English and other 'nations' of merchants present in the various coastal regions of the African continent had to adopt a variety of strategies. These ranged from transporting small pre-fabricated boats to the coast on board heavier ships and recruiting craftsmen specialized in ship repair and shipbuilding to acquiring African boats, either temporarily or permanently, and recruiting African boatmen. In this way, success on the coast was dependent on a combination of European and African shipbuilding craftsmanship and navigational skills.

The study starts by briefly examining the Dutch, English and Portuguese presence on the west coast of Africa during the relevant period. This is followed by an analysis of the pre-fabricated vessels used in the African coastal trade and the heavier ships employed in the long-distance commerce with the continent, of the workers responsible for maintaining and repairing these vessels on the coast, and of the canoes of African origin that were owned and employed by Europeans on the coast. The analysis included an examination of how these latter vessels were ordered, built and transported to the coast, and of the people involved. ${ }^{4}$

the Gold Coast during the Eighteenth Century (Philadelphia, 1989); Johannes M. Postma, The Dutch in the Atlantic Slave Trade, 1600-1815 (Cambridge, 1990); Henk den Heijer, De Geschiedenis van de WIC (Zutphen, 1994); Den Heijer, Goud, Ivoor en Slaven: Scheepvaart en Handel van de Tweede Westindische Compagnie op Afrika, 1674-1740 (Zutphen, 1997); Klaas Ratelband, Os Holandeses no Brasil e na Costa Africana: Angola, Kongo e S. Tomé (1600-1650) (Lisbon, 2003) [Dutch edition: Klaas Ratelband and René Baesjou, Nederlanders in West-Afrika 1600-1650: Angola, Kongo en São Tomé (Zutphen, 2000); Filipa Ribeiro da Silva, 'Dutch Trade with Senegambia, Guinea and Cape Verde, c. 1590-1674' in Toby Green, ed., Brokers of Change: Atlantic Commerce and Cultures in Precolonial Western Africa (Oxford, 2012), 125-148.

3. Klaas Ratelband, Vijf Dagregisters van het Kasteel Sao Jorge da Mina (Elmina) aan de Goudkust (1645-1647) (The Hague, 1953) and Filipa Ribeiro da Silva, 'Dutch Vessels in African Waters: Routes, Commercial Strategies, Trading Practices and Intra-Continental Trade (c. 1590-1674)', Tijdschrift voor Zeegeschiedenis, 29: 1 (2010), 19-38. See also: Feinberg, Africans and Europeans in West Africa.

4. On pre-fabricated ships built in the Republic, see: Remmelt Daalder, Schepen van de Gouden Eeuw (Amsterdam, 2005); Daalder, Maritieme Geschiedenis van Nederland: In 70 Hoogtepunten, 1500-2000 (Amsterdam, 2004); Daalder, 'Naval Battles to Order: Dutch History in Marine Paintings' in Jenny Gaschke, ed., Turmoil and Tranquility: The Sea Through the Eyes of Dutch and Flemish Masters, 1550-1700 (London, 2008), 11-21, and Marc van Alphen, Het Oorlogsschip als Varend Bedrijf. Schrijvers, Administratie en Logistiek Aan Boord van Nederlandse Marineschepen in de 17e en 18e Eeuw (Franeker, 2014). 
The analysis is based on information gathered from travelogues, journals of voyages and collections of correspondence exchanged between European merchants and their commercial agents in Africa, as well as between officials of the private European commercial companies active on the African coast.

\section{Dutch, English, Portuguese and other Europeans on the coast}

When the merchants of the Republic started their commercial activities on the west coast of Africa back in the 1590s, the only Europeans settled in various locations stretching from Arguin and Senegambia to the Gold Coast, and to Angola further south, as well as in the archipelagos of Cape Verde and São Tomé, were the Portuguese. Portugal's commercial presence in these regions was based on a monopoly held by the Portuguese Crown, and in which private merchants were authorized to participate, providing they obtained trading licences or were lease-holders of the monopoly and its various branches. The Portuguese held a privileged position in West and West Central Africa for over a century, without any significant competition. This changed, however, when the French, Dutch and English arrived towards the end of the sixteenth century. Unsurprisingly, the presence of merchants from these countries was not welcomed by officials of the Portuguese Crown and merchants operating within the Portuguese sphere of influence. Indeed the activities of these new arrivals in Africa were initially deemed illegal and those involved regarded as intruders.

During the early period of Dutch trade with West Africa and West Central Africa (1590s-1620s), commercial ventures were organized by private merchants based in major port cities in the Republic, such as Amsterdam, Rotterdam and Middelburg. The commercial transactions conducted consisted mainly in exchanges of European goods (primarily textiles and metal ware) for hides, ivory, gold, beeswax, ambergris and civet cats obtained in various coastal regions stretching from Senegambia to the Loango Coast, along with sugar from the island of São Tomé.

However, the Dutch Revolt against the Habsburg Empire in 1568 and the subsequent Eighty Years War (1568-1648), which increased political and military tensions between the Republic, Spain and Portugal and their subjects, both in Europe and overseas, led to increasing losses for the merchants engaged in overseas trade, including trade with West and West Central Africa. As a result, members of the mercantile community demanded the intervention of the Republic's States General. In response, the latter sponsored an expedition to São Tomé, with the aim of taking over the main island of the archipelago in the Gulf of Guinea. ${ }^{5}$

Despite the Twelve Years' Truce (1609-1621) between the Republic and the Habsburg Empire, merchants sailing under the Dutch flag continued to be attacked and to engage in conflict at sea with Portuguese and Spanish vessels. In response to demands from some sectors of the Republic's mercantile community, the States General therefore negotiated with the chief of Asebu, with the result that the Dutch were permitted to establish their first fortress on the Gold Coast, Fort Nassau, which was built in Mouri in 1612.

5. Adam Jones, ed., German Sources for West African History 1559-1669 (Wiesbaden, 1985), $9-17$. 
The end of the Truce intensified conflicts on the African coast and in the Atlantic in general, thus increasing the losses suffered by merchants and prompting demands for a more formal organization to be established to defend their interests. The States General responded in 1621 by chartering the West India Company ('WIC', or 'the Company') and granting it a monopoly on the overall Atlantic trade, including commerce with West and West Central Africa, and with the sole exception being the northern fisheries. Private trade with Africa was consequently prohibited between 1624 and 1638, with merchants' authorization to invest and participate in these commercial activities being restricted to three main capacities: as shareholders of the Company, if they were hired by the Company to provide shipping or other services, or if they were recruited as Company servants. ${ }^{6}$

However, the WIC itself then became involved in intense naval conflicts against Spanish and Portuguese vessels and the latter countries' territorial possessions in the Atlantic, including West and West Central Africa. These attacks resulted in the WIC capturing various trading posts and settlements in the 1630s and 1640s that had previously been controlled by the Portuguese, including Arguin, Mina, Axim, Shama, São Tomé and Angola.

The naval conflicts between the WIC and the Portuguese in the Atlantic and in West and West Central Africa continued in the years following the takeover of the above forts and territories. As well as disrupting the Company's trade on the African coast, these conflicts also increased military and naval expenditure, and put an enormous strain on logistics. ${ }^{7}$ To cope with the burden on its finances, shipping and personnel, the Company started to loosen its monopoly in the late 1630 s by allowing private merchants once again to participate in various commercial branches of the WIC monopoly, excluding the gold trade. However, despite this loosening of restrictions, neither the deals between Company and private merchants and the resultant injection of private capital nor the use of privately hired workers and materials were sufficient to prevent the Company from going bankrupt in 1674 .

By then, however, the States General had decided to charter a second Dutch West India Company, with identical jurisdiction over the coasts of West and West Central Africa. This second Company was granted a nominal monopoly over the Republic's trade in the Atlantic, including West and West Central Africa, and also the administrative, fiscal and military authority to enforce this monopoly. However, commercial transactions were in the hands of private merchants from the Republic and their partners. In time, therefore, the WIC became a primarily administrative, fiscal and military organization responsible for maintaining and administrating the Dutch strongholds and trading posts in West and West Central Africa, as well as for levying taxes on trade. This was reflected in the increasing activities performed by interlopers trespassing on the Company's monopoly, and in the formation of multiple small, medium and large-size

6. Filipa Ribeiro da Silva, Dutch and Portuguese in Western Africa: States, Merchants and the Atlantic System, 1580-1674 (Leiden, 2011), chapter 6.

7. Michiel A. G. de Jong, 'Staat van Oorlog': Wapenbedrijf en Militaire Hervorming in de Republik der Verenigde Nederlanden, 1585-1621 (Hilversum, 2005). See also: Louis Jadin, ed., L'Ancien Congo et l'Angola, 1639-1655 d'Après les Archives Romaines, Portugaises, Néerlandaises et Espagnoles, 3 vols. (Brussels/Rome, 1975). 
companies in several Dutch ports, of which the Middleburgse Commercie Compagnie ('MCC'), founded in 1720, was the best known example. ${ }^{8}$

During the seventeenth century, the English, Danish, Swedish and French also increased their presence in West Africa, firstly through private commercial ventures and later through chartered commercial companies, thus mirroring to a certain extent the Dutch WIC. The seventeenth century consequently witnessed the chartering of the Swedish West India Company (1637), the Company of Royal Adventurers Trading to Africa (1660) - later renamed the Royal African Company (RAC, and established in 1672) and the Gluckstadt Company (1659) - later designated the Danish West IndiaGuinea Company (1697), with these companies subsequently establishing themselves on the coast. Like their Portuguese and Dutch counterparts, these companies sought to ensure themselves of a permanent presence on the coast so as to safeguard their commercial interests. In seeking to achieve this aim, they attempted on various occasions to take over strongholds and trading posts from each other, as well as to outcompete their commercial rivals. Despite this commercial competition, however, the various Europeans operating on the west coast of Africa also showed themselves able to cooperate with each other in times of great need. And some of the areas in which such cases of great need were experienced included the ship maintenance and repair activities discussed below.

\section{Building, maintaining and repairing European vessels on the coast}

Until the first Dutch stronghold on the Gold Coast was built at Mouri in 1612, Dutch merchants relied on three main strategies to ensure they had the types of vessels they needed to trade on the coast and to ensure their vessels could be maintained and repaired, whenever needed. Firstly, the heavier ships heading to West Africa carried on board one or two pre-fabricated light boats or sloops..$^{9}$ These were often assembled and equipped with muskets and heavy guns when the vessels reached the African coast - often at specific locations such as the Cape Verde islands, Goree and Cape Lopez..$^{10}$ This assembly process could take between two and three weeks. As early as 1602, Pieter de Marees mentioned the transport, assembly and use of sloops in the coastal circuits of West Africa in his Description and Historical Account of the Gold Kingdom of Guinea. ${ }^{11}$ These light boats were essential for carrying crew members ashore, as well as for transporting

8. Ruud Paesie, Lorrendrayen op Afrika: De Illegale Goederen - en Slavenhandel op WestAfrika Tijdens het Achttiende-Eeuwse Handelsmonopolie van de West-Indische Compagnie, 1700-1734 (Amsterdam, 2008). On the MCC, see, among others, Corrie van Prooijen, 'Van Goederenhandel Naar Slavenhandel: De Middelburgse Commercie Compagnie 1720-1755' (unpublished PhD dissertation, Leiden University, 2000).

9. Sloop, from the Dutch sloep. In this context, the word refers to barges especially designed to navigate in rivers, canals and shallow waters.

10. J. D. La Fleur, trans. \& ed., Pieter van den Broecke's Journal of Voyages to Cape Verde, Guinea and Angola (1605-1612) (London, 2000), 87-91.

11. Albert van Dantzig and Adam Jones, trans. and eds., Pieter de Marees: Description and Historical Account of the Gold Kingdom of Guinea (1602) (Oxford, 1987), 8, 10. Also referred to in 'Andreas Josua Ulsheimer's Voyage of 1603-4', published in Adam Jones, ed., German Sources for West African History 1559-1669 (Wiesbaden, 1985), 20. 
merchandise for trade whenever transactions were done on the coast itself, while also being paramount for fetching wood, water and food supplies, and later for transporting slaves between the forts and trading posts, and to the heavier ships anchored there for trade. These sloops could also be entrusted to merchants and assistants who were temporarily placed on the coast to conduct trade, and who were often housed in accommodation rented from local women. This practice was common in the Petite Côte of Senegal, Cape Mount, Loango and Soyo. ${ }^{12}$ Ships heading further south, namely to the Grain, Ivory, Gold and Slave Coasts, also carried similar pre-fabricated sloops on board or, alternatively, acquired canoes of African craftsmanship locally.

This strategy seem to have been adopted by the Dutch because of their lack of control over the resources needed to produce vessels locally, with wood being by far the most important. The Dutch, as well as other Europeans, also often lacked sufficient numbers of skilled labourers able to perform those operations on the Atlantic African coast. Reduced or non-existent harbour infrastructures only made matters worse, with many harbours and anchoring bays only having capacity and facilities for simple repairs. This situation prevailed throughout the Early Modern period.

Secondly, and in view of the lack of local shipbuilding facilities, the only way that Dutch fleets heading to West and West Central Africa could guarantee a more or less permanent presence on the coast was to ensure their fleets comprised both heavier and lighter vessels. Usually, a lighter vessel (a yacht or barge) was sent with the fleet to remain on the coast as a floating trading post (or leggers) after the rest of the fleet had left for Europe with traded cargo. These small yachts or barges, usually with a capacity of 20 last ${ }^{13}$ were left at the coast under the responsibility of a chief merchant, commonly assisted by one or more junior merchants and assistants. Other crew members, some of whom would have had knowledge of ship repairs, ${ }^{14}$ were also likely to be on board the leggers, which, depending on their tonnage, could also be equipped with an additional sloop for contacts and trade with the coast. The sloop was used whenever the former was too heavy or deep to navigate closer to the coast and to enter the river estuaries, where trade was often conducted. These practices continued to be applied throughout the seventeenth and eighteenth centuries in places where the Dutch (as well as the English and other Europeans) had no permanent and properly equipped strongholds or trading posts.

Thirdly, for maintenance and repair purposes, the crews on heavier Dutch and English vessels often included men knowledgeable in carpentry and blacksmithing, while ships also needed to carry materials and spare parts on board to replace any damage or missing equipment. On 28 November 1682, for example, Hugo Shears, commander of the John anchored at the Mine River (Gold Coast), was assisted during his stay on the coast by the two carpenters serving on board the vessel commanded by Captain Branfill. On the same occasion, Captain Branfill also sent Commander Shears 'a barrel of pitch and 1 barrel of tarr' ${ }^{15}$ Ships regularly also provided other ships on the coast with materials and spare parts. On 23 June 1682, Samuel Starland, serving the RAC on board the African

12. La Fleur, trans. \& ed., Pieter van den Broecke's Journal, 28, 47, 74, 88.

13. One last $=2,000 \mathrm{~kg}$.

14. La Fleur, trans. \& ed., Pieter van den Broecke's Journal, 79, 88-9.

15. Robin Law, ed., The English in West Africa, 1681-1683: The Local Correspondence of the Royal African Company of England, 1681-1699: Part I (London, 1997), 276. 
Merchant, reported, for example, that he "was forced to buy an anchor out of a Dutchman that lay there [Allampo], by reason the anchor that [he] had [gotten] from the [Cape Coast] Briganteen would not ride the ship'. ${ }^{16}$ Evidence suggests, therefore, that commercial competition among Europeans on the coast of Atlantic Africa went hand-in-hand with aid.

It was also common for ships to request support from technical crew members on board other ships anchored along the coast and conducting trade. On 1 June 1682, for example, Ralph Hassell, serving the RAC at James Fort in Accra, reported that ' $\mathrm{Mr}$ Charles Towgood [commander of the Cape Coast Briganteen] [went] downe to Tishen about 4 leagues off [Teshi, east of Accra] to borrow some helpe of the carpenter of another ship [...].' ${ }^{17}$

After the Dutch and the English had established fortresses or trading posts on the coast, however, these establishments also started to provide certain services, such as ship maintenance and repairs, shipping of commodities, and provisioning between the shore and heavier vessels, as evidenced by Commander Hugo Shears, cited above, who wrote to the Cape Coast Castle requesting 'ocam [=oakum] [. . .] nailes and small spikes [. . . ] for the vessel' ${ }^{18}$

The Dutch WIC headquarters at Elmina Castle on the Gold Coast regularly housed a number of craftsmen, including carpenters and blacksmiths, whose tasks included working on the construction and repair of the fortress and other strongholds and trading posts on the coast, but also helping, wherever necessary, to maintain and repair ships. These craftsmen were expected to assist ships calling at the castle, as well as other trading posts, and the lighter vessels the Company kept more or less permanently on the coast for trading and patrolling purposes. ${ }^{19}$ Similar practices were found among the English. On 12 May 1682, for instance, Samuel Starland, on board the African Merchant anchored at Anishan Road, ${ }^{20}$ reported that: 'The $5^{\text {th }}$ instant att night wee sprang a great leake and have been ever since endeavouring to find it but cannot. [. . .] soe if your worship pleases to order mee up to have the advice of a carpenter [ . . . . ${ }^{21}$

Forts and trading posts needed to be equipped with certain essential materials if they were to carry out ship maintenance and repair work. Some of these materials were acquired locally; this included wood, for which demand was always high. As well as being vital for construction, cooking, heating and sometimes lighting at the fortresses and trading posts and on the vessels, wood was also essential for repairing both heavier and lighter ships. Procurement of high-quality wood (being the type not easily destroyed by worms), and especially of large beams, was therefore of key importance. Timber was obtained in areas away from the coast, often by Europeans placing orders with African middlemen or brokers, commonly referred to as Cabooceers in the Dutch sources. It was these Cabooceers who were responsible for acquiring and felling trees in the interior and

16. Law, The English in West Africa, Part I, 266.

17. Law, The English in West Africa, Part I, 188.

18. Law, The English in West Africa, Part I, 276.

19. Ratelband, Vijf Dagregisters, lvii-cx.

20. Location stated in the source. Meaning: anchored at Anishan.

21. Law, The English in West Africa, Part I, 264. 
for arranging to transport them to the coast, while the Europeans were often expected to pay the porters.

Two letters written in September 1681 by Arthur Richards, serving the RAC at the Anishan Factory, and addressed to the Company's headquarters in West Africa, give us a glimpse into these procedures. As Mr Richards wrote:

[. . . The curanteer says if you have occasion of any timber you may have what you please and he will not differe with you for wood. He has 20 or 30 great trees at a croome of his hard by, soe if you please to have any you may. [. . . I I am inform'd by the Curranteere itt is a sort of wood that the wormes will not take it. As for the price of the timber every joist will cost you 3 taccoes to bring downe, and when you have enough if you please to give the curanteere a small dashey $^{22}$ he will thank you for it, but he will not make a price with you for the timber. ${ }^{23}$

Once on the coast, the timber was transported to other trading posts and forts by canoe (of African design) or sloop. ${ }^{24}$ Other materials, however, were more difficult, if not impossible, to produce or obtain on the coast, and therefore had to be imported from Europe. These included carpentry tools, as well as nails and more technical shipbuilding parts, such as anchors and other instruments.

Whether obtained locally or imported from elsewhere, these materials were intended to be used to assist vessels that called at the fortresses and trading posts and stayed to trade on the coast for certain periods of time. However, repairs were not always easy to complete, as sometimes the required materials were lacking as Hugo Shears, Commander of the John, reported on 2 January 1681, 'The anchor that was mended at the Cape Corsoe the first time we put him on ground is broke as it was before, the which I have put on shoare at Amamaboe but there are not coals to mend it. ${ }^{25}$

These materials were also meant to be used for maintaining and repairing the lighter vessels the various companies regularly kept on the coast for trading purposes and for patrolling the coast in order to prevent smuggling activities by interlopers. On 23 June 1682, for instance, Charles Towgood, on board the Cape Coast Briganteen at Allampo Road, wrote:

I beleeve Mr. Smith informed your worship of the great leake I spring att Accra, since which I have spring another, they are both in the worst places of the vessel to be come att, [...]. The force of itt we have stop'd by stuffing in a great quantity of tallow and coals beaten together, nothing else being to be done. ${ }^{26}$

However, the repair needs of ships trading in the region were not always able to be met at Elmina Castle and the Cape Coast Castle. As a result, ships were sometimes forced to ask for help in the form of assistance with repairs, materials and spare parts from other ships trading in the region, sometimes even from ships sailing under the flag of rival or

22. Dash or dashey from the Portuguese dar or doação: gift.

23. Law, The English in West Africa, Part I, 75.

24. See, for example, Law, The English in West Africa, Part I, 78-83.

25. Law, The English in West Africa, Part I, 269.

26. Law, The English in West Africa, Part I, 274. 
enemy states or companies. On 23 June 1682, for example, Samuel Starland, serving the RAC on board the African Merchant, was forced, as mentioned earlier, ${ }^{27}$ to acquire an anchor from a Dutch ship.

The fortresses and trading posts were also expected to provide transport between the shore and the heavier ships so that merchandise, supplies, provisions, ammunitions, slaves and so on could be loaded and unloaded. These services were paramount if ships were to be dispatched as quickly as possible, given that a longer stay on the coast would increase transport and transaction costs. These shipments between the shore and vessels anchored in the roadstead were often carried by sloops that served fortresses and trading posts or by canoes crafted and operated by Africans, as evidenced by common references in the sources to the officials at several trading posts who wrote to the main headquarters on the Gold Coast requesting sloops (either new or used) and canoes for this purpose. This was common among both the Dutch and the English. ${ }^{28}$ Indeed, in the 1640s, the WIC had four yachts permanently stationed at Elmina. While the three heavier yachts were used for transporting products between Elmina and the different posts, as well as for conducting trade at the river mouths on the Slave Coast, the smaller yacht was used mainly for carrying firewood and water. ${ }^{29}$

\section{African shipbuilding and craftsmanship}

The View of Elmina referred to at the start of this article also shows details of African canoes on the shore near Elmina Castle and the nearby village (see Figure 1). Much of the coastal trade and communications between the various fortresses and trading ports, as well as shipments of commodities, provisions and ammunitions between the coast and the ships operating on the long-distance routes and that engaged in trade on the Gold Coast and nearby coasts, were handled by canoes such as these, crafted and operated by Africans. They were so important that on 19 August 1681, for instance, John Thorne, serving the RAC at Offra in Ardra, stated that 'without them nothing can be done'. ${ }^{30}$ The use and ownership of canoes appears to have been common in Dutch commercial operations on the coast, and the English appear to have learned from the Dutch practice, as suggested by the following passage in a letter written by Mark Bedford on 20 June 1683 while serving the RAC at Sekondi, and addressed to the latter's headquarters in West Africa (Cape Coast Castle). Mr Bedford wrote: '[ . . . I I am in want of a canoe and to hyre a canoe every time is chargeable, the Dutch have them here for that purpose. ${ }^{.31}$

Several scholars have referred to the canoe men employed by the European companies operating in West Africa, particularly on the Grain, Gold, Ivory and Slave Coasts. ${ }^{32}$ However, little attention has so far been paid to the canoes themselves. Strongholds and

27. Law, The English in West Africa, Part I, 266.

28. For examples of such requests in the case of the RAC, see Law, The English in West Africa, Part I, 4-5, 8, 221-3, etc. More examples can be found in volumes 2 and 3 of this source collection.

29. Ratelband, Vijf Dagregisters, lvii-cx.

30. Law, The English in West Africa, Part I, 221-3.

31. Law, The English in West Africa, Part I, 4.

32. Feinberg, Africans and Europeans in West Africa, and Ratelband, Vijf Dagregisters. 
posts could hire canoes and canoe men on the shore near the fortresses and trading posts to unload and load heavier ships, as well as when officials needed to send messages between trading stations. ${ }^{33}$

However, source materials also suggest that companies on the West African coast sometimes also owned one or more canoes of their own, and of varying sizes. ${ }^{34}$ Canoes were purchased on the coast through African middlemen with whom the Europeans conducted trade. These middlemen were then responsible for ordering the construction of the vessels further inland. According to the European sources, canoes were built away from the coast, in areas where supplies of wood, as well as craftsmen, were available. The canoes were not transported to the coast until they were finished, with the middlemen also being responsible for arranging to transport the canoes to the waterside. However, this was not always a quick process. On 21 August 1682, Robert Ware, commander of an unidentified ship at the service of the RAC anchored at Anomabu, reported:

I am much afraid that Mr. Richard will faile of his promise as to a canoe; for I understand that his people went to fetch her out of the woods but on Thursday last, but how long shee may be getting downe to the waterside is not yet knowne. Hee informs his people shee will be up in 3 dayes but itt is doubted by most people here. If hee come not according to his promise wee shall endeavor to purchase one here, which if procure will come att noe less price than a pound of gold, but she is a large canoe, therefore I earnestly begg your worship advice by the first. ${ }^{35}$

Moreover, negotiations to purchase canoes through local middlemen were not always easy, as Richard Thelwall, serving the RAC at Anomabu, reported on 26 August 1683:

This morning I received yours and as to purchase two 7 hand canoes, I believe it is impossible, but I believe they may get an 11 and a 9 hand canoe, but they are very deare, when they come down here they may make the bargaine themselves, $[\ldots] .{ }^{36}$

It also appears that, once built, canoes were not always easy to obtain, either for hire or purchase, as Richard Thelwall, serving the RAC at Anomabu, confirmed on 6 May 1683, when he said: 'As to a canoe, here is none to be got for love nor money. ${ }^{37}$ In An anonymous Dutch Manuscript dating from the mid-seventeenth century, it was also clearly stated that 'If you wish to trade here [Popo], you must bring a new strong canoe with you

33. There is also evidence of African slave pawns being employed as canoe men. RAC officials appear to have preferred them to the canoe men for hire. John Thorne, serving the RAC at Offra in Ardra, wrote: 'For canoemen I have 13 here, and if you send downe any more pray let them be pawns, for those which came with Captain Low proved rogues. For the last three days when there was most occasion for them, could not get them to carry oof the slaves to Captain Lowes great damage, but was forced to hyre other for which offence I hope your worship will be pleased to take it into consideration.' Law, The English in West Africa, Part I, 224.

34. European sources refer to canoe sizes in terms of 'hands'; in other words, to 2, 3, 5, 7, 9, 11 and 15-hand canoes.

35. Law, The English in West Africa, Part I, 320.

36. Law, The English in West Africa, Part I, 138.

37. Law, The English in West Africa, Part I, 131-2. 
from the Gold Coast with oarsmen, because here one cannot get through the surf in any boat.' 38

The problems experienced in obtaining African canoes were resolved in the same way as the problems relating to materials and craftsmen, which Europeans on the coast often borrowed from each other. On 18 August 1681, for instance, William Cross, serving the RAC at Offra in Ardra, reported to the Cape Coast Castle that 'att present we have none [canoe] but the 3 hand canoe to helpe our selves, and I have bin beholden to the Dutch for Captain Bowler and Captain Bramfill both, for the use of their canoes, whoe had 3 very good ones, but I have broke two by the badness of the weather'. ${ }^{39}$

Officials often complained that canoes were expensive, while their construction and delivery took a long time, and being poorly crafted meant they were easily destroyed. This was likely to be because they were constructed far away from the coast, in those areas where suitable wood was available, and only seasonally, with canoe crafting probably being combined with other activities. According to Richard Thewall, serving the RAC at Anomabu in 1681, 'the cheapest and best canoes are to be bought up to the windward at Axhim, [. . .].' ${ }^{40}$ In the following year, Richard Shepheard, serving the RAC at the same location, 'received from Mr. Thewall one 11 hand canoe, for which he paid 1 mark, and 4 ounces of gold' ${ }^{41}$

Canoe men appear to have been responsible not only for operating the canoes, but also for repairing them in the event of damage. On 24 June 1683, for instance, John Winder, serving the RAC at Whydah, reported that 'the canoemen have been forct to stay some time to repaire the canoe'. ${ }^{42}$ However, the damage was sometimes so extensive that repairs could not be done by local canoe men, and the canoes then ended up being sold to someone able to take them to other locations to be repaired. On 14 January 1683, Ralph Hassell, serving the RAC at James Fort in Accra, reported that 'the canoe which went up with Mr. Winder received very much damage, soe that I could not mend her here, so have sold her to Captain Branfill for 8 sletias'. ${ }^{43}$

\section{Conclusion}

Dutch and English shipbuilding, maintenance and repairs in Atlantic Africa during the Early Modern period can only be properly understood through a careful study of the interactions between Europeans and Africans on the coast, and the ways in which their respective traditions and knowledge of shipbuilding, maintenance and repair were articulated and combined, where we see clear signs of an entangled history. ${ }^{44}$

Evidence suggests that, for most of the Early Modern period, both the Dutch and the English lacked the necessary infrastructures to build ships (either lighter or heavier) in West Africa. The limited human and material resources deployed to this region were used mainly to

38. Adam Jones, ed., West Africa in the Mid-Seventeenth Century: An Anonymous Dutch Manuscript (1985), 187, 197, 206.

39. Law, The English in West Africa, Part I, 219-21.

40. Law, The English in West Africa, Part I, 96.

41. Law, The English in West Africa, Part I, 112.

42. Law, The English in West Africa, Part I, 254.

43. Law, The English in West Africa, Part I, 198.

44. Michael Werner and Bénédicte Zimmerman, eds., De la Comparaison à l'Histoire Croisée (Paris, 2004), 15-49. Werner and Zimmerman, 'Beyond Comparison: Histoire Croisée and the Challenge of Reflexivity', History and Theory, 45: 1 (2006), 30-50. 
maintain and repair ships operating on the long-distance routes and that anchored on the coast, as well as to maintain the lighter vessels employed in the coastal trade and for patrolling and defence purposes. These lighter ships (sloops and yachts) were also sent from Europe; first, in the earlier period of trade, by private merchants operating in the region, and later, after the chartered companies had been established, by these companies. However, these lighter vessels could also be acquired on the coast from other ships calling and trading in the region.

Both the Dutch and the English relied on African shipbuilding craftsmanship to construct and repair locally built canoes, which were purchased on the coast and widely employed in the coastal trade to load and unload heavier vessels anchored at the coast and to ensure communications between fortresses and trading posts. While the Dutch and English also relied heavily on African navigational skills to operate these canoes, the number of canoes available was often insufficient to service all the ships on the coast within the desired period of time. Many ships were consequently forced to carry their own sloops on board. Another reason why bringing sloops on board ships sailing from Europe was very important was because some trading ports lacked sloops or canoes for transporting shipments between the coast and the ships anchored in the roadstead and wanting to trade.

The strategies followed by the Dutch and the English in West Africa seem somewhat similar to those previously adopted by the Portuguese as, when heading for the coast, the latter fleets often included a smaller yacht used for transporting provisions, as well as small boats that could be used to transport goods between the shore and the heavier ships. The Portuguese also kept a small fleet on the Gold Coast, based at Castelo da Mina (later Elmina), for patrolling and defence purposes. ${ }^{45}$ The vessels based in the Cape Verde islands and the archipelago of São Tomé, which the Portuguese used in the coastal trade with nearby coastal areas such as Senegambia, Upper Guinea and the Gold, Ivory and Slave Coasts, also appear to have been built in Portugal and not locally. ${ }^{46}$

As in the Dutch and English cases, the main Portuguese ports in West and West Central Africa were often also main ports of call for vessels, and offered ship maintenance and repair services. Portuguese scholarship and primary sources remain relatively silent, however, on the use of African-built canoes and reliance on African shipbuilding craftsmanship. It is therefore paramount to include comparative studies of European and African shipbuilding craftsmanship during the Age of Sail in the future research agenda of maritime history in general and African maritime history in particular.

\section{Author biography}

Filipa Ribeiro da Silva is a Senior Researcher at the International Institute of Social History of the Netherlands Royal Academy of Arts and sciences. Filipa obtained her PhD at Leiden University in 2009, after reading History and History of Portuguese Oceanic Expansion at the New University of Lisbon, where she received her BA honours and Master degree in 1996 and 2002. Her research interests are Economic and Social History, Maritime History and Labour History. She has published on the Dutch and Portuguese in Western Africa and the Atlantic system, on labour migration to Atlantic Africa and on colonial population and labour relations in Mozambique.

45. De Marees, Description, 205-6.

46. See, among others, Leonor Freire Costa, Naus e Galeões na Ribeira de Lisboa: A Construção Naval no Século XVI para a Rota do Cabo (Cascais, 1997); Freire Costa, O Transporte no Atlântico e a Companhia Geral do Comércio do Brasil, 1580-1663 (Lisbon, 2002) and P. M. Laranjo Coelho, A Pederneira Apontamentos para a História dos seus Mareantes, Pescadores, Calafates e das suas Construções Navais nos Séculos XV e XVII (Lisbon, 1924). 